\title{
ORGANIZATIONAL COMMITMENT LEVELS OF PRESCHOOL TEACHERS AND ADMINISTRATORS' LEADERSHIP STYLES
}

PROBLEMS

OF EDUCATION

IN THE $21^{\text {st }}$ CENTURY

Vol. 79, No. 2, 2021

207

\author{
Kamil Arif Kırkıc \\ Istanbul Sabahattin Zaim University, Turkey \\ E-mail: kamil.kirkic@izu.edu.tr \\ Türkan Demir Balcı \\ Ministry of National Education, Turkey \\ E-mail: turkkan_28@hotmail.com
}

\begin{abstract}
The organizational commitment levels of preschool teachers are crucial to have an effective early childhood education. One of the most influential factors affecting organizational commitment is administrators' leadership style. This research explored the correlation between administrators' leadership styles and organizational commitment levels of preschool teachers. The correlational survey design was used as one of the quantitative research models in this study. Participants in the study were preschool teachers in Istanbul's Küçükçekmece district. The research was conducted during the 2017-2018 academic year. There are 237 teachers in the study sample. The 5-point Likert type Organizational Commitment Scale with 27 items and the Leadership Style Scale with 35 items were used to collect data. It was found that teachers generally identified with their organizations and internalized the organization's values, while school administrators were perceived as using a transformational leadership style. The study found a statistically significant correlation between the leadership styles of administrators and the levels of organizational commitment of preschool teachers. In preschool institutions, teachers' institutional commitment is essential for the development of students. Therefore, administrators should be sensitive to their leadership styles to make the commitment levels of preschool teachers high. The research has limitations like being a local one, done in a relatively short time, and the participants were only teachers working in public schools.
\end{abstract}

Keywords: leadership style, organizational commitment, preschool teacher, correlational survey, educational leadership

\section{Introduction}

The most crucial responsibility in educational institutions that strive for perfection lies with the institution managers to work effectively. The most significant difference between a high-performance educational institution and a low-performance educational institution is the institution managers' effectiveness in these institutions. This suggests that it is the leadership style demonstrated by institution managers that enables educational institutions to progress effectively. These managers should plan and fulfill their work following accepted rules. Managers of educational institutions play a crucial role in deciding educational quality. Their leadership styles greatly influence managers' ability to unlock the school's full potential. The organizational commitment of teachers and administrators is accepted as an indicator in determining an educational institution's success (Banjarnahor et al., 2018).

For an educational organization to have committed employees, those in management have significant responsibilities because the organization's success relies on its employees and 
Kamil Arif KIRKIÇ, Türkan Demir BALCI. Organizational commitment levels of preschool teachers and administrators' leadership styles

PROBLEMS

OF EDUCATION IN THE $21^{\text {st }}$ CENTURY Vol. 79 , No. 2, 2021

208

is directly related to management's level of influence and authorization. The more effective the leader is in communicating the duties and objectives of the institution to the employees, the more successful those people will be in adapting to the corporate atmosphere (Avc1, 2015, p.88).

In an educational institution, administrators and teachers influence each other. Through this interaction, school administrators must play an active role in achieving the institution's goals, increasing teachers' affiliation to the institution, addressing the situations that teachers want, and impacting them. From another perspective, organizational commitment means embracing the organization's interests and success in all its effectiveness (İbicioğlu, 2000). Leadership behavior was also stated as a factor in studies conducted to determine the factors affecting organizational commitment (Çetin, 2004). According to some researchers, the behaviors and practices of those acting as leaders affect employees' organizational commitment.

\section{Research Focus}

Employees show low commitment to an organization when they believe leaders are not helpful (Zangora, 2001). Due to the essential connection between organizational commitment and the leadership styles owned by administrators, different leadership styles should be evaluated to examine the commitment levels of all employees. Leadership approaches cannot be separated from the social and political characteristics of society. A successful leader examines the social structure and acts following its social and cultural features. A leader should consider the institution's diversity as part of its wealth and work to unite all aspects. A leader must influence all people, have good communication skills, have a holistic approach, know the strengths and weaknesses of employees, have a positive approach, be fair, and make decisions guided by equality criteria (Kantos, 2011).

The importance of leadership has been highlighted and expressed in terms of the leadership styles best suited to preparing the ground for achieving organizational goals and self-sacrificing work within an institution (Abasilim et al., 2019). The leader and their employees influence each other. When the leader's influence varies according to the individual characteristics of the audience, one should look at the quality of the leader and the qualities of the employees. While the leadership and management approach of the 19th Century was based on a structure of tradition, new approaches to leadership have arisen, which are very different (Y1ldırım, 2006). Transformational leadership, sustaining leadership, and laissez-faire leadership are the three types of leadership defined by researchers (Yalçın, 2014).

The transformational leader attaches importance to new approaches and focuses on explaining the organization's mission. This type of leader attempts to remain loyal to his ideals and create reliability, honesty, and respect. A transformational leader has high performance, broad experience, and adequate working power, which differs from managerial behavior based on tradition. They are also less confused about tasks. In short, transformational leaders exhibit the behaviors, values, and ideals of a leader (Hoşcan et al., 2004). Transformational leaders work on adding value to the community's goals beyond their own individual goals. School administrators who exhibit transformational leadership behavior create trust, respect, cooperation, high motivation, and loyalty among their employees (Gardner, 2018). Past studies report that transformational leadership is more effective, productive, and innovative. Through transformational leadership in educational institutions, an effort is made to satisfy employees, to bring them together in a shared vision, and to act in line with common goals (Chiun Lo et al., 2009).

In transactional leadership, employees are rewarded if they comply with the operational standards, focus on achieving institutional goals, and complete their work. It is a form of leadership that is supported by bureaucratic supervision and forms a legally determined 
position of duty, stating that problems may arise if tasks are not completed (Özgener \& Kılıç, IN THE $21^{\text {st }}$ CENTURY 2009). A transactional leader enables employees to work by making positive use of their past Vol. 79, No. 2, 2021 experiences or to make them more useful. Less attention is paid to employees being productive and innovative. Besides hard and disciplined work, such leaders tend to be tolerant, wise, and satisfied when work progresses according to the organizational plan and discipline (Eren, 2018).

The liberal leader offers endless rights to employees and prepares an environment for them to act independently. These leaders refrain from giving feedback to their employees by avoiding openly speaking up regarding events and situations that matter. Such leaders want to maintain existing conditions in the institution (Akan et al., 2017). According to this approach, a leader is the person who least deserves the right to lead. Leaders allow employees to work in line with their strengths and exhibit behaviors that allow them to make their goals and arrangements in line with their individual resources. In other words, leaders who allow complete freedom do not claim rights and empower employees (Karip, 1998).

While it is accepted that the concept of organizational commitment defines the relationship between the organization and its functions, discussion continues about the nature of the concept. Organizational commitment, organizational psychology, and organizational behavior are topics that are continually increasing in the literature. Both theoretical and practical efforts have been taken in increasing interest in organizational commitment in order to reveal results and expectations. The organizational commitment process helps recognize hidden meanings for employees (Okçu, 2011). Organizational commitment is defined as the relative strength of an individual's participation in a particular organization and how they identify with the organization. Organizational commitment is about adopting organizational values, being committed to the organization, and having the desire to participate in the work that needs to be done. As seen in the literature, organizational commitment comprises at least three elements (Çokluk \& Yilmaz, 2010).

1. A strong belief in, and a recognition/acknowledgment of, the goals and values of the organization,

2. Putting in significant effort for the organization,

3. Remaining as a member of the organization.

Organizational culture and organizational commitment are two integrated concepts. Since organizational commitment is employees' adoption of organizational culture, values, and goals, the organizational culture is critical for those organizations to have a high level of commitment. This suggests that by ensuring the desire of new members of an organization to be a part of the organizational culture, its expectations will be met. Success is achieved when organizational culture is accepted and adopted by employees (Erceylan, 2010).

Organizational commitment is classified as affective commitment, continuance commitment, normative commitment (Allen \&Meyer, 1990, p.3). These conceptual structures refer to the link between the organization and the employee. Affective commitment, where employees desire to remain in the organization, develops from their positive experiences. Employees' needs determine continuance commitment in terms of the social and economic cost of leaving the organization. In addition, normative commitment is the employees' feeling that it is necessary to remain in the organization (Türkmen, 2016).

Compliance, recognition, and internalization are the three dimensions of organizational engagement. Individuals have adopted the organization's goals and authority to receive incentives or avoid punishment (O'Reily \& Chatman, 1986, p. 493). Celep (2014, p. 16) has stated that compliance in such situations occurs when employees go beyond the expectations of others in order to achieve the awards, they deem personally necessary. Individuals behave out of necessity, not because they believe in the organization. Harmony is always imperative. Managers may use their authority to ensure that employees carry out their requests, so employees must obey. However, such compliance is done reluctantly. According to Handy, this type of 
Kamil Arif KIRKIÇ, Türkan Demir BALCI. Organizational commitment levels of preschool teachers and administrators' leadership styles

PROBLEMS

OF EDUCATION IN THE $21^{\text {st }}$ CENTURY Vol. 79 , No. 2, 2021

210

adaptation brought about by necessity has been based on control rather than trust and eliminates the individual's right to choose (cited in Balay, 2000, p.104). In schools where altruism and selfsacrifice are expected, teachers do not feel a commitment to the organization, which negatively affects the educational activities, quality, and effectiveness of schools (İmamoğlu, 2011, p.29). The administrators and educators of institutions with high organizational commitment create a reliable and successful working atmosphere, the execution of sustainable studies, the desired level of individual and academic progress, and the training of self-confident and self-accepting people. These administrators and educators increase their employees' commitment to their organizations, support their personal development through proper study, provide more support and innovative studies to students, and allocate more time to the institution. These behaviors also contribute to the success of the institution (Avc1, 2017, p.67).

Internalization, the final element of commitment, is the harmony of personal and organizational values and the effect of organizational values on employees' behavior. For internalization, the individual must voluntarily accept and adopt organizational values as their values, without elements of coercion. Therefore, internalization includes normative commitment (Balc1, 2003). This type of commitment is most helpful to organizations because internalization is independent of the origin of the source of influence. However, there is less chance of success, and it takes a longer time to develop. When internalization occurs, it is not necessary to find new resources to convince employees continually. With this commitment, employees accept the new ideas, developments, and behavior as their own (Balay, 2000). According to Heidmets and Liik, the leadership styles of administrators can be a factor in determining teachers' commitment to school and their emotional attachment to the school (2014). In some research studies, it was found that teacher commitment was linked explicitly to principals' leadership behaviors (Da'as, 2020; Freeman \& Fields, 2020; Griffioen \& de Jong, 2017).

\section{Research Aim and Research Questions}

This study aimed to search the correlation between the leadership styles of administrators in terms of the perceptions of preschool teachers and the levels of organizational commitment of preschool teachers. The key research question was whether there was a correlation between administrators' leadership styles according to preschool teachers' perceptions and preschool teachers' organizational commitment levels. To this end, the study sought to find answers to the following questions:

a) What is the level of teachers' organizational commitment?

b) According to teachers' perceptions, what kind of leadership styles do school administrators show?

c) Is there a significant correlation between the leadership styles of school administrators and the organizational commitment of teachers?

d) Do leadership styles of administrators predict the organizational commitment of preschool teachers?

\section{Research Methodology}

\section{General Background}

The research was carried out by using the relational survey model in order to determine the correlation between the levels of the organizational commitment of teachers and the leadership styles of school administrators. Survey models attempt to explain an existing situation in the past or present. The survey model is the arrangements made on the entire group or a sample to reach a general judgment about many elements of the whole group (Karasar, 2017). The research was conducted in the 2017-2018 academic year. The total duration for the research was eight months. 
Kamil Arif KIRKIÇ, Türkan Demir BALCI. Organizational commitment levels of preschool teachers and administrators' leadership styles

The population of the research were 596 teachers working in the independent public kindergartens in the Küçükçekmece district of Istanbul and as well as in the kindergartens within public primary, secondary, and high schools. The number of teachers to be sampled was calculated to be at least 234 within a $95 \%$ confidence level and a 5\% margin of error. The calculation was done by using the Raosoft sample size calculator (Raosoft, 2018). The sample consists of 237 teachers, and they were selected through a random sampling method from among 596 teachers. Of the teachers in the sample group, 55 (23.2\%) were in the 25 and under-age group, $84(35.4 \%)$ in the 26-30 age group, 54 (22.8\%) in the 31-35 age group, 44 $(18.6 \%)$ in the 36 and over age group. Of them, 145 teachers $(61.2 \%)$ work in independent kindergarten, and 92 (38.8\%) in kindergarten within primary, secondary, and high schools. One hundred and sixty-one of the teachers (67.9\%) worked for 1-3 years at their current school, and $76(32.1 \%)$ have worked for four years or more. Necessary permissions were obtained from the Ministry of Education. Verbal consent was obtained from the participants. They were told that they could stop answering the questionnaires and participate in the study if they were not volunteers anymore.

\section{Instrument and Procedures}

The questionnaire to collect the research data includes the "Organizational Commitment Scale", first developed by Balay (2000). The scale consists of three sub-dimensions, compliance, identification, and internalization. It was prepared as a 5-point Likert type rating from (1) Strongly Disagree to (5) Very Strongly Agree. The compliance sub-dimension of the organizational commitment scale consists of items 1-8, the identification sub-dimension contains items 9-16, and the internalization sub-dimension contains items 17-27. Analyses can be made on factor scores for three factors in the scale, and a single score cannot be obtained from the scale. In the study, the Cronbach's alpha reliability coefficient was calculated as .82 for the compliance sub-dimension, .90 for the identification sub-dimension, and .90 for the internalization sub-dimension.

The second scale that the research employed was the "Leadership Style of School Administrators Scale," developed by Akan, Yıldırım, and Yalçın (2014). The scale is prepared as a 5-point Likert type scale rating from (1) Strongly Disagree to (5) Strongly Agree. The scale consists of three sub-dimensions: transformational leadership style, transactional leadership style, and laissez-faire leadership style. Cronbach's alpha reliability coefficient was .95 for transformational leadership, .65 for transactional leadership, and .87 for laissez-faire leadership.

\section{Data Analysis}

The data obtained in the study was coded and loaded into the computer and analyzed using the "SPSS 25.0 for Windows" statistical program. The skewness and kurtosis values were used to determine whether the data had a normal distribution. The values were determined as 1.00 and 1.15 in the "compliance" sub-dimension of the organizational commitment subdimension, -.57 and .11 in the "identification" sub-dimension, -. .40 and .76 in the "internalization" sub-dimension, and -.63 and 1.25 in the whole organizational commitment scale. The "transformational leadership" sub-dimension of the leadership styles of school administrators was calculated as -.43 and .59, the " transactional leadership" sub-dimension as .04 and .35, and the " laissez-faire leadership" sub-dimension as .64 and .60. These were accepted as normal distribution because Tabachnick and Fidell (2013) accept the data distribution as normal when the skewness and kurtosis values are within the range of \pm 1.5 . According to George and 
Kamil Arif KIRKIÇ, Türkan Demir BALCI. Organizational commitment levels of preschool teachers and administrators' leadership styles

PROBLEMS

OF EDUCATION IN THE $21^{\text {st }}$ CENTURY Vol. 79 , No. 2, 2021

Mallery (2010), the skewness and kurtosis values being within \pm 2 intervals is acceptable for normality. Based on these expressions, the distribution is accepted as normal.

Pearson Product Moment Correlation Analysis was used to determine the correlation between preschool teachers' organizational commitment and school administrators' leadership style. Regression analysis was conducted to determine to what extent the leadership styles of school administrators affect teachers' organizational commitment.

\section{Research Results}

\section{Leadership Styles of Administrators According to Preschool Teachers' Perceptions And Organizational Commitment Levels of Preschool Teachers}

As can be seen in Table 1, organizational commitment levels of preschool teachers are primarily in the "internalization" sub-dimension, followed by the "identification" sub-dimension, and the least in the "compliance" sub-dimension. Organizational commitment perceptions of teachers are at the level of "absolutely disagree" in the "compliance" sub-dimension; "I agree" in the "identification" sub-dimension; and "I agree" in the "internalization" sub-dimension.

Table 1

Arithmetic Average and Standard Deviation Values of the Organizational Commitment Scale Sub-Dimensions

\begin{tabular}{lll}
\hline Dimensions & $\boldsymbol{M}$ & $\boldsymbol{S D}$ \\
\hline Compliance & 1.74 & 0.59 \\
Identification & 3.81 & 0.77 \\
Internalization & 3.89 & 0.60 \\
\hline
\end{tabular}

Table 2 shows the Leadership Styles Scale Sub-Dimensions. As shown in Table 2, according to the perceptions of the teachers, school administrators mostly have a "transformational leadership" style $(M=4.08)$, then a "transactional leadership" style $(M=2.57)$, and the least have a " laissez-faire leadership" style. $(M=1.93)$ according to the perceptions of the teachers. At the "I accept" level, the school administrators displayed "transformational leadership"; at the "indecisive" level, they displayed "transactional leadership"; and at the "disagree" level, they displayed "laissez-faire leadership".

Table 2

Arithmetic Average and Standard Deviation Values of School Administrators' Leadership Styles Scale Sub-Dimensions

\begin{tabular}{lll}
\hline Dimensions & $\boldsymbol{M}$ & $\boldsymbol{S D}$ \\
\hline Transformational Leadership & 4.08 & 0.59 \\
Transactional Leadership & 2.57 & 0.61 \\
Laissez-Faire Leadership & 1.93 & 0.68 \\
\hline
\end{tabular}


Kamil Arif KIRKIÇ, Türkan Demir BALCI. Organizational commitment levels of preschool teachers and administrators' leadership styles

Evaluation of the Correlation between the Administrators' Leadership Style and Preschool Teachers' Organizational Commitment

PROBLEMS

OF EDUCATION

IN THE $21^{\text {st }}$ CENTURY

Vol. 79, No. 2, 2021

213

Table 3 shows the result of the Pearson correlation analysis conducted to determine whether there is a statistically significant correlation between the sub-dimensions of the leadership styles scale of school administrators and the sub-dimensions of the organizational commitment scale. There was a statistically significant negative correlation between "transformational leadership" and "compliance" $(r=-.467 ; p<.01)$. There is a statistically significant positive correlation between "transformational leadership" and "identification" $(r=.630 ; p<.01)$. There was a statistically significant positive correlation between "transformational leadership" and "internalization" $(r=.514 ; p<.01)$. There was a statistically significant positive correlation between "transactional leadership" and "compliance" ( $r=.431 ; p<.01)$. There was a statistically significant negative correlation between "transactional leadership" and "identification" ( $r=$ $-.385 ; p<.01)$. There was a statistically significant negative correlation between "transactional leadership" and "internalization" $(r=-.266 ; p<.01)$. There was a statistically significant positive correlation between "laissez-faire leadership" and "compliance" $(r=.487 ; p<.01)$. There was a statistically significant negative correlation between "laissez-faire leadership" and "identification" $(r=-.505 ; p<.01)$. There was a statistically significant negative correlation between "laissez-faire leadership" and "internalization" ( $r=$-. 399; $p<.01)$.

Table 3

Pearson Correlation Analysis Results Conducted to Determine the Correlation between Preschool Administrators' Leadership Styles and Teachers' Organizational Commitment

\begin{tabular}{lllll}
\hline Dimensions & & Compliance & Identification & Internalization \\
\hline Transformational Leadership & $\mathrm{r}$ & -.467 & .630 & .514 \\
\cline { 2 - 5 } & $\mathrm{p}$ & .0001 & .0001 & .0001 \\
\hline Sustainable Leadership & $\mathrm{r}$ & .431 & -.385 & -.266 \\
\cline { 2 - 5 } & $\mathrm{p}$ & .0001 & .0001 & .0001 \\
\hline Laissez-Faire Leadership & $\mathrm{r}$ & .487 & -.505 & -.399 \\
\cline { 2 - 5 } & $\mathrm{p}$ & .0001 & .0001 & .0001 \\
\hline
\end{tabular}

Evaluation of School Administrators' Leadership Styles Predicting

Preschool Teachers' Organizational Commitment

A regression analysis was conducted to explore the prediction level of school administrators' leadership styles on organizational commitment levels of preschool teachers. The regression analysis in Table 4 reveals that transformational leadership style explains $22 \%$ of the total variance of the compliance dimension $\left(R^{2}=.218 ; p<.001\right)$ and $26 \%$ of the total variance of the internalization dimension $\left(R^{2}=.264 ; p<.001\right)$. Furthermore, the transformational leadership style explains $40 \%$ of the identification dimension's total variance $\left(R^{2}=.397 ; p<.001\right)$.

Transactional leadership style explains $19 \%$ of the total variance of compliance dimension of organizational commitment $\left(R^{2}=.186 ; p<.001\right), 15 \%$ of the total variance at the level of identification dimension $\left(R^{2}=.148 ; p<.001\right)$, and $7 \%$ of the total variance at the internalization dimension level $\left(R^{2}=.071 ; p<.001\right)$. 
Kamil Arif KIRKIÇ, Türkan Demir BALCI. Organizational commitment levels of preschool teachers and administrators' leadership styles

PROBLEMS

OF EDUCATION IN THE $21^{\text {st }}$ CENTURY Vol. 79, No. 2, 2021

Laissez-Faire leadership style explains $24 \%$ of the total variance of compliance dimension of organizational commitment $\left(R^{2}=.237 ; p<.001\right), 26 \%$ of the total variance of identification dimension $\left(R^{2}=.255 ; p<.001\right)$, and $16 \%$ of the total variance at the internalization dimension $\left(R^{2}=.159 ; p<.001\right)$.

Table 4

Regression Analysis Results Related to the Level of Leadership Styles of School Administrators Predicting Teachers' Organizational Commitment

\begin{tabular}{lllllllll}
\hline Independent Variable & $\begin{array}{l}\text { Dependent } \\
\text { Variable }\end{array}$ & $\boldsymbol{B}$ & $\boldsymbol{S E}$ & $\boldsymbol{( \beta )}$ & $\boldsymbol{R}$ & $\boldsymbol{R}^{2}$ & $\boldsymbol{F}$ & $\boldsymbol{p}$ \\
\hline $\begin{array}{l}\text { Transformational } \\
\text { Leadership }\end{array}$ & Compliance & -.47 & .11 & -.47 & .467 & .218 & 65.456 & .001 \\
\cline { 2 - 8 } & Identification & .82 & .07 & .63 & .630 & .397 & 154.93 & .001 \\
\cline { 2 - 8 } & Internalization & .52 & .06 & .51 & .514 & .264 & 84.431 & .001 \\
\hline \multirow{2}{*}{$\begin{array}{l}\text { Transactional } \\
\text { Leadership }\end{array}$} & Compliance & .42 & .06 & .43 & .431 & .186 & 53.686 & .001 \\
\cline { 2 - 8 } & Identification & -.49 & .08 & -39 & .385 & .148 & 49.887 & .001 \\
\cline { 2 - 8 } & Internalization & -.26 & .06 & -27 & .266 & .071 & 17.858 & .001 \\
\hline \multirow{2}{*}{$\begin{array}{l}\text { Laissez-Faire } \\
\text { Leadership }\end{array}$} & Compliance & .42 & .05 & .49 & .487 & .237 & 72.869 & .001 \\
\cline { 2 - 8 } & Identification & -.58 & .06 & -51 & .505 & .255 & 80.606 & .001 \\
\cline { 2 - 8 } & Internalization & -.35 & .05 & -40 & .399 & .159 & 44.576 & .001 \\
\hline
\end{tabular}

\section{Discussion}

The first question addressed what the level of teachers' organizational commitment was. Teachers' perceptions of organizational commitment were high in the internalization and identification sub-dimensions but were low in the compliance sub-dimension.

School administrators' leadership styles affect teachers' well-being, which contributes to their commitment to the school (Heidmets \& Liik, 2014). In the study conducted in Estonian public schools, it was found that school administrators 'higher transformational leadership approach was closely related to the decrease in teachers' job quitting and burnout and thus the coat of arms of their commitment to the school (Heidmets \& Liik, 2014).

The second question addressed what kind of leadership styles that school administrators showed according to teachers' perceptions. Findings showed that according to the teachers' perceptions, the transformational leadership style was the most common, the transactional leadership style was the second most common style, and the laissez-faire leadership style was the third most common style.

In order to increase teachers' commitment to the school, the management should support new teachers, especially when they are new to the profession. Supporting transformational leadership approaches will contribute to teachers' holding on to their institutions in the future (Kugiejko, 2015). According to the results of a meta-analytic study done by Kaya and Selvitopu (2017), especially teacher commitment would be increased if managers possessed transformational and instructional leadership styles. Considering that teachers who work with school administrators with supportive leadership have higher organizational commitment 
levels, school administrators 'more supportive leadership will increase teachers' commitment to the school. (Çokluk \& Y1lmaz, 2010). Liu and Watson found that teachers' involvement in decision-making mechanisms was one of the factors that increased their commitment to school. Therefore, as transformational leaders, school leaders should consider teachers' involvement, particularly in matters related to instructional and teacher development. (2020). Only in this way can teachers' organizational commitment be strengthened and supported.

The third question of the research addressed whether there was a significant correlation between school administrators' leadership styles and preschool teachers' organizational commitment. Although there was a statistically significant negative correlation between transformational leadership and compliance, the correlation between transformational leadership and identification was a statistically significant positive one. Also, there was a statistically significant positive correlation between transformational leadership and internalization. When the relation between transactional leadership and three dimensions of teachers' organizational commitment sub-dimensions were analyzed, there was a statistically significant positive correlation between transactional leadership and compliance. However, the correlation between transactional leadership style and other two dimensions, identification, and internalization, were statistically significant negative ones. The third leadership style, laissez-faire leadership, had a statistically significant negative correlation with all sub-dimensions of organizational commitment, compliance, identification, and internalization.

Akan and Yalçın (2015) found a statistically significant positive correlation between the identification and internalization sub-dimensions of organizational commitment and transformational leadership style. A statistically significant positive correlation was found between teachers' perceptions of sustaining leadership style and compliance commitment and a negative relation between identification commitment and internalization commitment. Yalçın (2014) found a statistically significant positive correlation between transformational leadership style and organizational commitment. Okçu (2011) found that transformational leadership had a positive effect on organizational commitment.

Akan and Yalçın (2015) found a statistically significant negative correlation between the transactional leadership style and the internalization and identification sub-dimensions of organizational commitment. A statistically significant positive correlation was found between teachers' perception of laissez-faire leadership style and compliance commitment and a negative correlation between identification commitment and internalization commitment. Akan and Yalçın (2015) found a statistically significant negative correlation between the laissez-faire leadership style and the internalization and identification sub-dimensions of organizational commitment. The correlation between administrators' laissez-faire leadership style and organizational commitment was high; therefore, the existing relation could affect the crucial factors such as job satisfaction (Banjarnahor et al., 2018).

The last question of the research addressed whether the leadership styles of administrators predicted the preschool teachers' organizational commitment. The transformational leadership style explains $22 \%$ of the total variance of the compliance dimension, $26 \%$ of the total variance of the internalization dimension, and $40 \%$ of the identification dimension's total variance. In comparison, the transactional leadership style explains $19 \%$ of the total variance of the compliance dimension of organizational commitment, $15 \%$ of the total variance at the level of identification dimension, and $7 \%$ of the total variance at the internalization dimension level. The third type of leadership, the laissez-faire leadership style, explains $24 \%$ of the total variance of the compliance dimension of organizational commitment, $26 \%$ of the total variance of identification dimension, and $16 \%$ of the total variance of internalization dimension.

School administrators having transformational leadership characteristics contribute to creating a positive attribution that teachers will develop a positive approach (Da'as, 2020). Transformational leadership can increase the commitment levels of teachers, but instructional 
Kamil Arif KIRKIÇ, Türkan Demir BALCI. Organizational commitment levels of preschool teachers and administrators' leadership styles

PROBLEMS

OF EDUCATION IN THE $21^{\text {st }}$ CENTURY Vol. 79, No. 2, 2021

216

leadership increases teachers' commitment to the school by increasing collaboration among teachers (Cansoy, Parlar, \& Polatcan, 2020).

Contrary to this result, it was found that the leadership styles of the administrators were limited in the faculty's understanding and adoption of institutional goals. During organizational change, by increasing the participation of lecturers in the decision-making process, lecturers effectively adopt goals in organizational structures rather than managers' leadership styles (Griffioen \& de Jong, 2017). Although this research's transformational leadership has a significant effect on teachers' school commitment, there are also other types of leadership like servant leadership that affects the organizational commitment levels of teachers (Cerit, 2010). Another study determined that transformational leadership is related to teachers' organizational trust but not to teacher commitment (Freeman \& Fields, 2020). Like in this study, Khasawneh, Omari, and Abu-Tineh found that transformational leadership had a strong effect on the organizational commitment of vocational school teachers (2012). Leadership styles of school principals affect both their organizational commitments and job satisfaction (Banjarnahor et al., 2018). The findings of this study can be used to increase teacher commitment. If the administrators of preschool schools want their teachers to be highly committed to the school, it is recommended that they should adopt transactional leadership as their leadership style. When different leadership styles are adopted, it would be helpful to consider the possible commitment levels of teachers according to the results of the research.

\section{Conclusions and Implications}

It has been determined that preschool teachers show organizational commitment at the highest level of internalization, medium level identification, and the lowest compliance level. It was found that teachers perceived school administrators as transformational leaders, they were indecisive in their perception as a supplementary leader, and their perception of liberator leaders was weak. Pre-school teachers' perceptions of the transformational leadership style negatively correlated with compliance commitment, and there was a significant positive relation between identification commitment and internalization commitment.

This research was conducted by collecting data with scales and using different information acquisition tools and methods. More detailed results can be achieved by using quantitative and qualitative research studies together. Measures should be taken to ensure that educators can work more effectively, using their transformational leadership qualities to manage people's skills. School administrators can adopt participatory, transformational leadership understanding in order to gain transformational leadership skills and to increase the organizational commitment of teachers in the organization. The management of institutions can take in-service training seminars to increase their awareness of the desired leadership behaviors.

In the education field, this research aimed to examine whether there was a relation between administrators' leadership styles and preschool teachers' organizational commitment levels according to preschool teachers' perceptions. Because in preschool institutions, teachers' institutional commitment is essential for the development of students. It is vital for administrators to be aware of this and to know the impact of the leadership styles they adopt on teachers' commitments.

This research has different limitations. The first of these limitations is that the participants are only teachers working in public schools. Besides, the fact that the study is local and that it is done in a relatively short time is among the limitations of the study.

Despite the limitations mentioned above, it presents essential findings and comments for policymakers in the selection and training of school administrators, preschool teachers, and educational administrators in order to reveal the correlation between preschool teachers' organizational commitment levels and school administrators' perceived leadership styles. In 
order to help teachers and administrators to understand each other in preschool institutions, it

appears that the leadership styles of administrators affect them in terms of teachers.

\section{Acknowledgments}

The authors would like to thank all teachers who participated in the research and Carol Williams; Kasım Varlı for the English language review. The second author's graduate thesis was used to write this article, which the first author supervised.

\section{References}

Abasilim, U., Gberevbie, D., \& Osibanjo, O. (2019). Leadership styles and employees' commitment: Empirical evidence from Nigeria. SAGE Open, 9(3), 1-15. https://doi.org/10.1177\%2F2158244019866287

Akan, D., Yalçın, S., \& Yıldırım, İ. (2017, May 11-13). Okul yöneticilerinin liderlik stilleri ile öğretmenlerin pozitif psikolojik sermaye düzeyleri arasındaki ilişkinin incelenmesi. [Investigation of the relationship between leadership styles of school administrators and teachers' positive psychological capital levels]. 12th International Educational Management Symposium, Ankara, Turkey.

Akan, D., Yıldırım, İ., \& Yalçın, S. (2014). Okul Müdürlerinin Liderlik Stili Ölçeğinin Geliştirilmesi (OMLSÖ) [Developing leadership style scale of school principals (OMLSÖ)]. Elektronik Sosyal Bilimler Journal, 13(51), 392-415. https://doi.org/10.17755/esosder.28743

Akan, D., \& Yalçın, S. (2015). Okul yöneticilerinin liderlik stilleri ile öğretmenlerin örgütsel bağlılıkları arasındaki ilişkinin incelenmesi [Examining the relationship between school administrators 'leadership styles and teachers' organizational commitment]. Journal of Education and Humanities: Theory and Practice, 6(11), 123-150.

Allen, N. J., \& Meyer, J. P. (1990). The measurement and antecedents of affective, continuance, and normative commitment to the organization. Journal of Occupational Psychology, 63(1), 1-18. https://doi.org/10.1111/j.2044-8325.1990.tb00506.x

Avcı, A. (2015). Örgütsel vatandaşlık davranışları: kavramsal gelışımı ve eğıtım örgütlerı açısından etk1leri [Organizational citizenship behaviors: Its conceptual development and its effects on educational organizations]. Hasan Ali Yücel Eğitim Fakültesi Journal, 12(2), 11-26.

Avcı, A. (2017). Örgütsel bağl1lık: Kavramsal çerçevesi ve eğitim örgütleri açısından etkileri [Organizational commitment: Its conceptual framework and its effects on educational organizations]. International Periodical for the Languages, Literature and History of Turkish or Turkic, 12(6), 55-76. http://dx.doi.org/10.7827/TurkishStudies.11535

Balay, R. (2000). Özel ve resmi liselerde yönetici ve öğretmenlerin örgütsel bağglllı̆gl [Organizational commitment of administrators and teachers in private and public high schools] [Unpublished doctoral dissertation]. Ankara University.

Balc1, A. (2003). Örgütsel sosyalleşme kuram strateji ve taktikler [Organizational socialization theory, strategy and tactics]. Pegem A Publications.

Banjarnahor, H., Hutabarat, W., Sibuea, A. M., \& Situmorang, M. (2018). Job satisfaction as a mediator between directive and participatory leadership styles toward organizational commitment. International Journal of Instruction, 11(4), 869-888. https://doi.org/10.12973/iji.2018.11455a

Celep, C. (2014). Eğitim örgütlerinde örgütsel adanma [Organizational commitment in educational organizations]. Nobel Publications.

Cerit, Y. (2010). The effects of servant leadership on teachers' organizational commitment in primary schools in Turkey. International Journal of Leadership in Education, 13(3), 301317. https://doi.org/10.1080/13603124.2010.496933

Chiun, Lo, M., Ramayah, T., \& Wei Min, H. (2009). Leadership styles and organizational commitment: A test on Malaysia manufacturing industry. African Journal of Marketing Management, 1(6), 133139. https://doi.org/10.1080/13602380903355676

Çetin, M. (2004). Örgüt kültürü ve örgütsel băglllık [Organizational commitment in educational organizations]. Nobel Publications. 
Kamil Arif KIRKIÇ, Türkan Demir BALCI. Organizational commitment levels of preschool teachers and administrators' leadership styles

PROBLEMS

OF EDUCATION IN THE $21^{\text {st }}$ CENTURY Vol. 79, No. 2, 2021

218

Çokluk, Ö., \& Yılmaz, K. (2010). The relationship between leadership behavior and organizational commitment in Turkish primary schools. Bilig, 54, 75-92.

Da'as, R. (2020). Between principals' and a teacher's perspective taking: the role of transformational and transactional leadership styles. International Journal of Leadership in Education, 1-23. https://doi.org/10.1080/13603124.2020.1850871

Erceylan, N. (2010). Yöneticilerin liderlik davranışlarının çalışanların örgütsel bağlılıkları üzerindeki etkileri ve bir araştırma [The effects of managers 'leadership behaviors on employees' organizational commitment and a research] [Unpublished master's thesis]. İnönü University.

Eren, E. (2018). Stratejik yönetim ve işletme politikası [Strategic management and business policy]. Beta Publications.

Freeman, G. T., \& Fields, D. (2020). School leadership in an urban context: Complicating notions of effective principal leadership, organizational setting, and teacher commitment to students. International Journal of Leadership in Education, 1-21. https://doi.org/10.1080/13603124.2020.1818133

Gardner, A. (2018). The relationship between organizational commitment and transformational and transactional leadership styles in government contract employees [Unpublished doctoral dissertation]. Liberty University.

George, D., \& Mallery, M. (2010). SPSS for windows step by step: A Simple Guide and Reference, 17.0 Update, (10th Edition). Pearson.

Griffioen, D.M.E., \&. de Jong, U. (2017) The influence of direct executive managers on lecturers' perceptions on new organizational aims in times of academic drift. International Journal of Leadership in Education, 20(4), 451-467. https://doi.org/10.1080/13603124.2015.1066867

Heidmets, M., \& Liik, K. (2014). School principals' leadership style and teachers' subjective well-being at school. Problems of Education in the 21st Century, 62, 40-50.

Hoşcan, Y., Oktal, Ö., Hepkul, A., Kağnıcıŏlu, H., \& Sevim, A. (2004). Yönetim bilgi sistemi [Management information system]. AÖF Publications.

İbicioğlu, H. (2000). Örgütsel bağl1lıkta paradigmatik uyumun yeri [The place of paradigmatic fit in organizational commitment]. Dokuz Eylül Üniversitesi İktisadi İdari Bilimler Fakültesi Journal, $15(1), 13-22$.

İmamoğlu, G. (2011). İlköğretim okulu öğretmenlerinin örgütsel bağhllık düzeyleri ve örgütsel adalet algıları arasındaki ilişki [The relationship between primary school teachers' organizational commitment levels and their perceptions of organizational justice] [Unpublished master's thesis]. Gazi University.

Kantos, E. Z. (2011). Örgüt metaforlarında liderlik: Kavramsal bir çözümleme [Leadership in organizational metaphors: A conceptual analysis]. Eğitim Bilimleri Araştırmalart Journal, 1(1), $135-158$.

Karasar, N. (2017). Bilimsel araştırma yöntemi [Leadership in organizational metaphors: a conceptual analysis]. Nobel Publications.

Karip, E. (1998). Dönüşümcü liderlik [Transformational leadership]. Kuram ve Uygulamada Eğitim Yönetimi Journal, 4(16). https://dergipark.org.tr/en/pub/kuey/issue/10380/127019

Kaya, M., \& Selvitop, A. (2017). Leadership and organizational commitment in educational context: A meta- analytic review. Dicle University Journal of Ziya Gökalp Faculty of Education, (31), 719728. https://doi.org/10.14582/DUZGEF.1822

Khasawneh, S., Omari, A., \& Abu-Tineh, A. M. (2012). The relationship between transformational leadership and organizational commitment: The case for vocational teachers in Jordan. Educational Management Administration \& Leadership, 40(4), 494-508. https://doi.org/10.1177/1741143212438217

Kugiejko, M. (2015). A professional skill set of a teacher and university lecturer in relation to the causes and prevention of job burnout. Problems of Education in the 21st Century, 67, 40-51. http://www.scientiasocialis.lt/pec/files/pdf/vol67/40-51.Kugiejko_Vol.67_PEC.pdf

Liu, Y., \& Watson, S. (2020). Whose leadership role is more substantial for teacher professional collaboration, job satisfaction and organizational commitment: A lens of distributed leadership. International Journal of Leadership in Education, 1-29. https://doi.org/10.1080/13603124.2020 .1820580

Okçu, V. (2011). Okul yöneticilerinin liderlik stilleri ile öğretmenlerin örgütsel bağlllıkları ve yıldırtma yaşama düzeyleri arasındaki ilişkilerin incelenmesi [Examining the relationship between leadership styles of school administrators and teachers' organizational commitment and intimidation] [Unpublished master's thesis]. Gazi University. 
Kamil Arif KIRKIÇ, Türkan Demir BALCI. Organizational commitment levels of preschool teachers and administrators' leadership styles

O'Reilly, C. A., \& Chatman, J. (1986). Organizational commitment and psychological attachment: The effects of compliance, identification, and internalization on prosocial behavior. Journal of Applied IN THE $21{ }^{\text {st }}$ CENTURY Vol. 79, No. 2, 2021 Psychology, 71(3), 492-499. https://doi.org/10.1037/0021-9010.71.3.492

Özgener, S., and Kılıç, G. (2009, May 21- 23). Eğitim kurumlarında liderlik tarzları ve örgüt kültürünün performans üzerindeki etkisi [Leadership styles in educational institutions and the impact of organizational culture on performance]. 17th National Management and Organization Congress, Eskişehir, Turkey. http://w3.balikesir.edu.tr/ seymen/yonetim.pdf

Raosoft. (2018). Raosoft sample size calculator. [Software]. http://www.raosoft.com/samplesize.html

Tabachnick, B. G., \& Fidell, L. S. (2007). Using multivariate statistics (5th Edition). Allyn and Bacon.

Türkmen, F. (2016). Ortaokul yöneticilerinin hizmetkar liderlik davranışlarının öğretmenlerin örgütsel bă̆lllıklarl üzerindeki etkisi [The effect of middle school administrators 'servant leadership behaviors on teachers' organizational commitment] [Unpublished master's thesis]. Ondokuz Mayis University.

Yalçın, S. (2014). Öğretmenlerin algılarına göre okul yöneticilerinin liderlik stilleri ile öğretmenlerin iş yaşam kalitesi ve örgütsel bağlllık düzeyleri arasındaki ilişkinin incelenmesi [Investigation of the relationship between school administrators' leadership styles and teachers' work quality of life and organizational commitment according to teachers' perceptions] [Unpublished doctoral dissertation]. Ataturk University.

Yıldırım, C. (2006). Okul müdürlerinin liderlik stillerinin örgütsel sağlık üzerindeki 211 etkisi [211 effects of school principals' leadership styles on organizational health]. [Unpublished master's thesis]. Gazi University.

Zangora, G. (2001). Organizational commitment: A concept analysis. Nursing Forum, 36(2), 14-21. https://doi.org/10.1111/j.1744-6198.2001.tb01179.x

Received: December 26, 2020

Accepted: March 24, 2021

Cite as: Kırkıç, K. A., \& Balci, T. D. (2021). Organizational commitment levels of preschool teachers and administrators' leadership styles. Problems of Education in the $21^{\text {st }}$ Century, 79(2), 207-219. https://doi.org/10.33225/pec/21.79.207

Kamil Arif Kırkıç

(Corresponding author)
PhD, Assistant Professor, Istanbul Sabahattin Zaim University, Halkalı Cad. No: 281 Halkalı Küçükçekmece, Istanbul, Turkey.

E-mail: kamil.kirkic@izu.edu.tr

ORCID: https://orcid.org/0000-0002-8902-437X

Ministry of National Education, Turkey.

E-mail: turkkan_28@hotmail.com 